Int. J. Morphol.,

29(3):1054-1057, 2011.

\title{
Intraparotid Facial Nerve Neurofibroma: an Uncommon Neoplasm
}

\author{
Neurofibroma Intraparotídeo del Nervio Facial: una Neoplasia Poco Frecuente
}

Ashwani Sethi; Shamit Chopra; J. C. Passey \& A. K. Agarwal

SETHI, A.; CHOPRA, S.; PASSEY, J. C.; AGARWAL, A. K. Intraparotid facial nerve neurofibroma: an uncommon neoplasm. Int. J. Morphol., 29(3):1054-1057, 2011.

SUMMARY: Intraparotid facial nerve neurofibromas are a rare entity, and are grossly and histopathologically distinct from the comparatively more prevalent schwannomas. We report a rare case of an intraparotid facial nerve neurofibroma with intratemporal extension in a 48-year-old female. The tumor was surgically excised with cable grafting of the facial nerve. Electroneurography may eventually assist in the preoperative diagnosis. Facial nerve resection should be more readily contemplated in a patient with neurofibroma than in a patient with schwannoma; however, facial nerve preservation with serial follow-up electroneurography and computerized tomography remains a viable option in patients with small facial nerve neurofibromas when electrical testing reveals minimal evidence of progressive neural degeneration. Close monitoring, especially in neurofibromas associated with Von Recklinghausen's disease, is mandatory because of an increased risk of sarcomatous degeneration.

KEY WORDS: Facial nerve; Neurofibroma; Parotid gland; Temporal bone; Nerve grafting.

\section{INTRODUCTION}

Neurogenic neoplasms of the facial nerve are uncommon. Tumors occurring in the intraparotid portion of the facial nerve are rarer still (Brettau et al., 1983; Kavanaugh \& Panje, 1982). These tumors arise from schwann cells, and the benign neoplasms are classified into two types: schwannoma (more common) and the exceedingly rare neurofibroma, of which there are fewer then twenty reported cases in English literature (McGuirt et al., 2003; Souaid et al., 2002; Moberly \& Fritsch, 2009; Feng et al., 2008; Liu et al., 2007; McMonagle et al., 2006; Fierek et al., 2006). The extreme rarity of occurrence of this entity has prompted us to report this case.

\section{CASE REPORT}

A 48-year-old female presented with weakness of the left side of face of 2 years duration. She also complained of decreased hearing in the left ear with aural fullness for 2 years. She had previously been diagnosed as a case of middle ear tumor, and reported to us with an inconclusive histopathology report. Review sections revealed the tumor as being of neurogenic origin, in all probability a neurofibroma. On examination, left-sided facial paresis was present. No mass was identified in the left external auditory canal, and the tympanic membrane was intact. No abnormal cutaneous pigmentation or mass lesion was identified on general physical examination. A pure tone audiogram revealed a conductive hearing loss of $30 \mathrm{~dB}$ in the left ear, computerized tomography showed a heterogenous enhancing soft tissue mass involving left jugular fossa, mastoid region and petrous temporal bone with minimal destruction. MRI showed an irregular altered intensity lesion in the left temporal and parotid regions, measuring 3 by $2.5 \mathrm{~cm}$ (Fig. 1). Routine blood and urine investigations were normal. A left transparotid transmastoid excision of the tumor under general anesthesia was done. During the surgery, the tumor was found encasing the facial nerve $1 \mathrm{~cm}$ proximal to the division of the main trunk into its terminal branches. An area of cystic 
degeneration was identified within the tumor (Fig. 2). The tumor involved the parotid gland in the tragal pointer region, breaching the floor of the external auditory canal to involve the hypotympanum, mesotympanum, mastoid antrum and periantral mastoid air cells reaching till the level of the lateral sinus. Excision of the tumor with greater auricular nerve grafting between the proximal one-third of mastoid segment

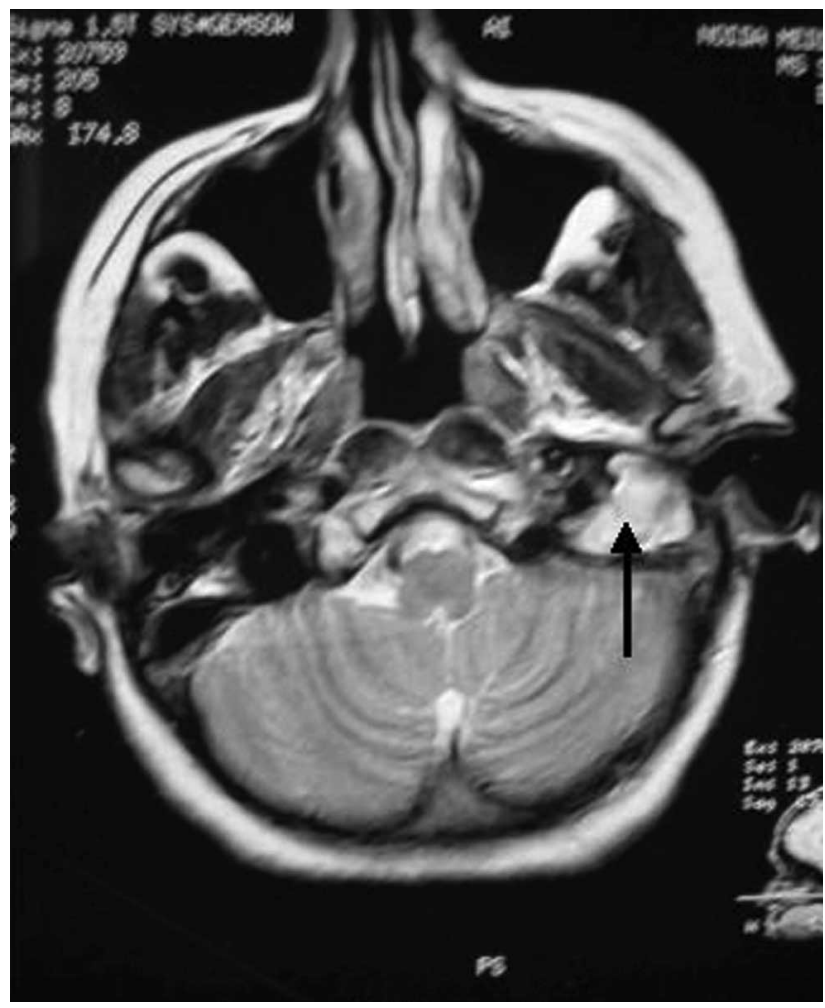

Fig. 1. MRI Scan (Axial view) showing the tumour (Black Arrow).

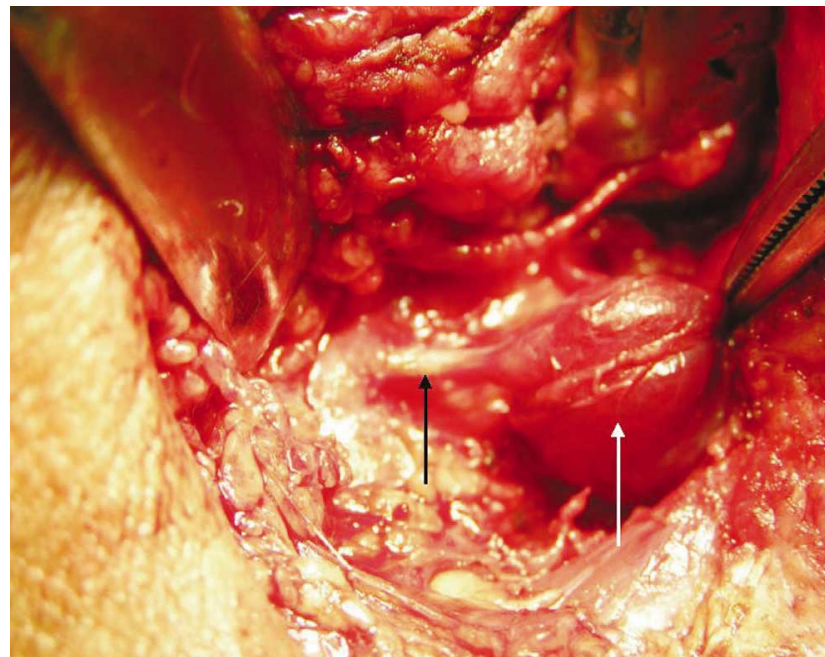

Fig. 2. Intraoperative photograph showing the facial nerve (Black Arrow) engulfed by the tumour with cystic changes in the tumour White Arrow). of facial nerve and the main trunk $0.5 \mathrm{~cm}$ proximal to its division into its terminal branches was done. The histopathological evaluation of the excised specimen was consistent with a neurofibroma (Figs. 3 and 4). Eighteen months post-operatively, the patient is well, without any evidence of recurrence, and with a residual facial paresis comparable to the pre-operative levels.

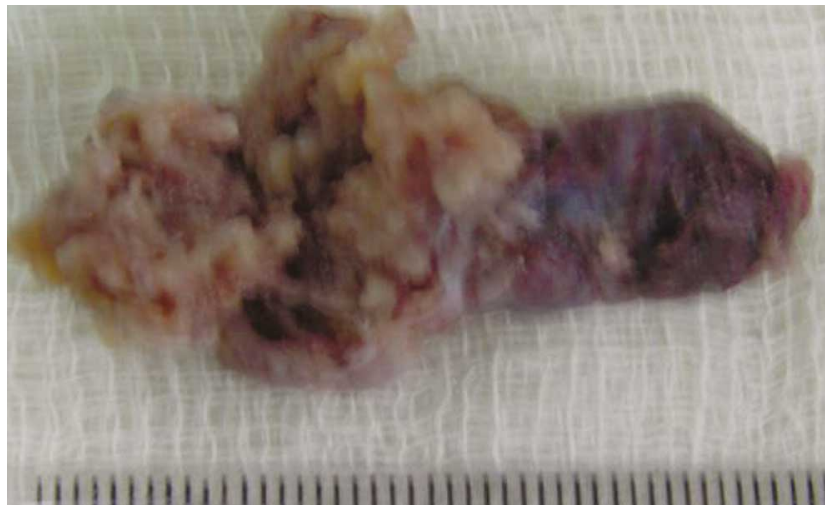

Fig. 3. Excised specimen.

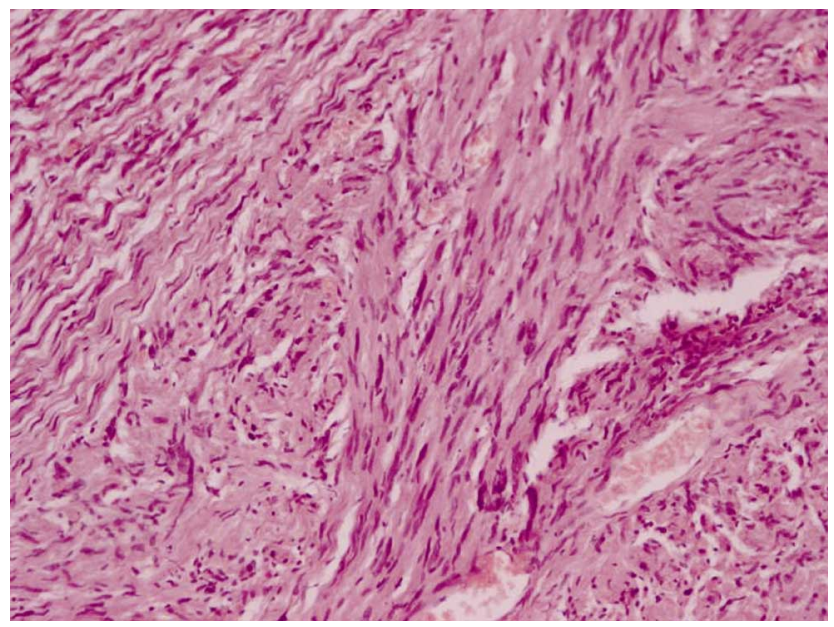

Fig. 4. Spindle cells in a loosely arranged collagenous matrix. H \& E Staining, $250 \mathrm{X}$.

\section{DISCUSSION}

Intraparotid facial nerve tumors are rare and unlikely to be included in the differential diagnosis of a parotid mass. Nearly half of these extratemporal tumors involve the main trunk of the nerve (Conley \& Janecka, 1973). No characteristic symptom profile exists. However, pain, tenderness, facial spasm or paralysis may be present. Our patient had facial paresis and hearing loss as her chief complaints. A non-diagnostic fine needle aspiration is typical of these tumors, given the extreme difficulty in obtaining 
positive cytology in neurogenic neoplasms. The rarity of positive cytology may be secondary to the adhesive nature of cells in such tumors (Brettau et al.).

Grossly, schwannomas are solitary, encapsulated tumors usually attached to or surrounded by nerve. It appears to push axons aside and degenerative changes like cystic alterations or hemorrhagic necrosis are usually present. In contrast, the neurofibroma is nonencapsulated and frequently multiple. Axons pass directly through neurofibromas and regressive changes are less common. Neurofibromas may occur most commonly as a part of a syndrome of neurofibromatosis 1 (Von Recklinghausen's disease), as solitary neurofibromas or as multiple neurofibromas without Von Recklinghausen's disease (Sullivan et al., 1987). Our case falls in the second of the above mentioned categories, and also showed an area of cystic degeneration.

Histologically, schwannomas and neurofibromas show some distinctive features. Two microscopic patterns of schwannomas exist, Antoni A and Antoni B. Antoni A lesions are characterized by broad interlacing ribbons of extended spindle cells with elongated nuclei arranged in waves, drifts and whorls. On cross section, these cylindrical cells produce a palisading pattern of nuclei about a central mass of cytoplasm called a Verocay body. Antoni B pattern is made up of very loose tissue, lacking the arrangement in the bundle and palisades, and is thought to be a degenerative form of Type A with a looser texture and polymorphism of cells. Neurofibromas are characterized by relatively scant, haphazard arrangement of delicate spindle cells among a loosely textured collagenous matrix, and may also incorporate nerve fibers within the tumour matrix. In this way, the cellular pattern of neurofibroma is much looser than that of a schwannoma (Sullivan et al.).

Malignant transformation of neurofibromas is uncommon but does occur; it has been reported to be $10-15 \%$ in plexiform neurofibromas. This is commoner than in the case of schwannomas; and sarcomatous transformation in a neurofibroma is commoner in NF1-associated and deeply seated tumors (McGuirt et al.; Sullivan et al.).

The role of electrodiagnostic studies in the evaluation of intratemporal tumours is debatable. Occasional preoperative abnormalities in facial electroneurography even when clinical facial nerve function is normal have been noted. Such abnormalities in preoperative electrical testing may be indicative of subclinical neural degeneration (Kartush et al., 1985).

Management of neurogenic tumors of the intraparotid facial nerve is controversial. Schwannomas tend to displace nerves and thus allow for nerve preservation procedures. Neurofibromas, however, incorporate nerves and are generally resected en bloc with the involved nerve. En bloc resection with cable grafting is recommended when nerve fibers are tenuous and interspersed within the tumor capsule (Kavanaugh \& Panje; Conley, 1975). The issue of facial nerve function is thus central to the treatment of benign neurogenic facial nerve neoplasms. Certainly the rare malignant tumor needs surgical extirpation when confined by respectable surgical margins, and every parotid mass associated with facial nerve weakness or paralysis should be biopsied. The tumors in most such cases will be malignant. Controversy arises in the treatment of benign tumors with intact facial nerve function. Some authors state that the results with facial nerve reconstruction are better when there is no preoperative facial weakness rather than in the presence of a long-standing palsy (Sullivan et al.). In contrast, others recommend that resection not be performed when all clinical parameters suggest a benign neuroma: intraoperative tumor appearance, inseparability from the facial nerve, and facial movement elicited by electrical stimulation of the tumor (May, 1986). In such a scenario, the option of following benign neurogenic lesions with serial electroneurography and computerized tomography appears feasible. Such an approach may be quite palatable for elderly patients who continue to have good facial function; and may have a greater opportunity to defer resection for patients in whom progressive degeneration is unlikely (Sullivan et al.).

SETHI, A.; CHOPRA, S.; PASSEY, J. C.; AGARWAL, A. K. Neurofibroma intraparotídeo del nervio facial: una neoplasia poco frecuente. Int. J. Morphol., 29(3):1054-1057, 2011.

RESUMEN: Los neurofibromas intraparotídeos del nervio facial son una entidad poco frecuente, macroscópicamente e histopatológicamente diferentes de los comparativamente más frecuentes schwannomas. Se presenta un caso raro de un neurofibroma del nervio facial con extensión intraparotídea intratemporal en una mujer de 48 años de edad. El tumor se extirpó quirúrgicamente con injerto del nervio facial. La electroneurografía puede llegar a ayudar en el diagnóstico preoperatorio. La resección del nervio facial debe ser realizada con mayor facilidad en un paciente con neurofibroma que en un paciente con schwannoma, sin embargo, la preservación del nervio facial con electroneurografía de seguimiento y tomografía computarizada sigue siendo una opción viable en pacientes con pequeños neurofibromas del nervio facial, cuando las pruebas eléctricas revelan mínima evidencia de degeneración neuronal progresiva. Una estrecha vigilancia, especialmente en los neurofibromas asociados con la enfermedad de Von Recklinghausen es fundamental debido al aumento del riesgo de degeneración sarcomatosa.

PALABRAS CLAVE: Nervio facial; Neurofibroma; Glándula parótida; Hueso temporal; Injerto de nervio. 


\section{REFERENCES}

Brettau, P.; Melchiors, H. \& Krogdahl, A. Intraparotid neurilemmoma. Acta Otolaryngol., 95(3-4):382-4, 1983.

Conley, J. J. Neurilemmoma of the facial nerve. In: Salivary glands and the facial nerve. New York, Grune and Stratton, 1975. pp.103-5.

Conley, J. \& Janecka, I. Neurilemmoma of the facial nerve. Plast. Reconstr. Surg., 52(1):55-60, 1973.

Feng, G. D.; Gao, Z. Q.; Ni, D. F.; Wang, W. Z.; Jiang, H.; Quan, S. M. \& Zha, Y. Clinical analysis of primary facial nerve neuroma. Zhonghua Er Bi Yan Hou Tou Jing Wai Ke Za Zhi, 43(1):32-6, 2008.

Fierek, O.; Laskawi, R. \& Kunze, E. Solitary intraparotid neurofibroma of the facial nerve. Symptomatology, biology and management. HNO, 54(10):772-7, 2006.

Kartush, J. M.; Lilly, D. J. \& Kemink, J. L. Facial electroneurography: clinical and experimental investigations. Otolaryngol. Head Neck Surg., 93(4):516-23, 1985.

Kavanaugh, K. T. \& Panje, W. R. Neurogenic neoplasms of the seventh clinical nerve presenting as a parotid mass. Am. J. Otolaryngol., 3(1):53-6, 1982.

Liu, L.; Yang, S.; Han, D.; Huang, D. \& Yang, W. Primary tumours of the facial nerve: diagnostic and surgical treatment experience in Chinese PLA General Hospital. Acta Otolaryngol., 127(9):993-9, 2007.

May, M. Tumors involving the facial nerve. In: The Facial Nerve. New York, Thieme Inc., 1986. pp.455-67.

McGuirt, W. F. Sr.; Johnson, P. E. \& McGuirt, W. T. Intraparotid facial nerve neurofibromas. Laryngoscope, 113(1):82-4, 2003.

McMonagle, B.; Turner, J. \& Fagan, P. Intratemporal facial neurofibroma. Otol. Neurotol., 27(7):1045-6, 2006.

Moberly, A. C. \& Fritsch, M. H. Chorda tympani and facial nerve neurofibroma presenting as chronic otomastoiditis. Otolaryngol. Head Neck Surg., 140(3):429-30, 2009.

Souaid, J. P.; Nguyen, V. H.; Zeitouni, A. G. \& Manoukian,
J. Intraparotid facial nerve solitary plexiform neurofibroma: a first pediatric case report. Int. J. Pediatr. Otorhinolaryngol., 67(10):1113-5, 2003.

Sullivan, M. J.; Babyak, J. W. \& Kartush, J. M. Intraparotid facial nerve neurofibroma. Laryngoscope, 97(2):219-23, 1987.

Correspondence to:

Dr. Ashwani Sethi

Department of ENT \& Head and Neck Surgery

Maulana Azad Medical College and associated L. N. Hospital

E-80, Naraina Vihar

New Delhi-110028

INDIA.

Phone No: 91-11-55342404

Email: dr_sethi@rediffmail.com

Received: 05-09-2010

Accepted: 04-04-2011 